\title{
PENETAPAN KADAR FENOLIK TOTAL EKSTRAK METANOL KELOPAK BUNGA ROSELLA MERAH (Hibiscus sabdariffa Linn) DENGAN VARIASI TEMPAT TUMBUH SECARA SPEKTROFOTOMETRI
}

\section{DETERMINATION OF TOTAL PHENOLIC CONTENT OF METHANOLIC EXTRACTS RED ROSELL (Hibiscus sabdariffa Linn) CALYXS IN VARIATION OF GROWING AREA BY SPECTROPHOTOMETRY}

\author{
Riza Alfian, Hari Susanti \\ Fakultas Farmasi, Universitas Ahmad Dahlan, Yogyakarta
}

\section{Abstrak}

Penelitian ini bertujuan untuk menetapkan kadar fenolik total pada kelopak bunga rosella merah (Hibiscus sabdariffa Linn) dengan variasi tempat tumbuh. Kelopak bunga Rosella merah diambil dari daerah Glagah, Kediri dan Samigaluh. Senyawa fenolik dalam kelopak bunga rosella diekstraksi menggunakan metode maserasi dengan pelarut metanol. Kadar fenolik total ditetapkan menggunakan metode Spektrofotometri visibel dengan pereaksi Folin Ciocalteau. Prinsip dari metode ini adalah terbentuknya senyawa kompleks berwarna biru dari fosfomolibdatfosfotungstat yang direduksi senyawa fenolik dalam suasana basa yang dapat diukur secara spektrofotometri. Sebagai pembanding digunakan asam galat. Kadar fenolik total pada kelopak bunga Rosella merah Glagah, Kediri dan Samigaluh berturut-turut yaitu 1,40 g GAE/100 g ekstrak, SD 0,06 dengan n=12; 1,41 g GAE/100 g ekstrak, SD 0,07 dengan $n=12$ dan 2,12 g GAE/100 g ekstrak, SD 0,05 dengan $n=15$. Dapat disimpulkan bahwa tempat tumbuh berpengaruh terhadap kadar fenolik total dalam ekstrak metanol kelopak bunga Rosella merah.

Kata kunci : Rosella (Hibiscus sabdariffa Linn), fenolik total, metode Folin ciocalteau, variasi tempat tumbuh 


\section{Abstract}

The purpose of this research is to determine the total phenolic content of Hibiscus sabdariffa calyx in variations of growing area. Red Rosell calyxs were collected from Glagah, Kediri and Samigaluh. Phenolic compounds of Hibiscus sabdariffa calyx were extracted using maceration method with methanol. Total phenolics content were determined using visible spectrophotometry method with Folin Ciocalteau reagent. The principle of this method is the formation of blue complex compound from phospomolybdate-phosphotungstate reduced by phenolic compound in the basic condition, which can be measured by spectrophotometry. Galic acid was used as comperator in this research. Total phenolic content in red calyx Glagah, Kediri and Samigaluh were respectively $1.40 \mathrm{~g}$ GAE/100 g extract, SD $0.06(n=12), 1.41 \mathrm{~g}$ GAE/100 g extract, SD 0.07 ( $n=12)$ dan $2.12 \mathrm{~g}$ GAE/100 g extract, SD $0.05(n=15)$. Based on this results it could be concluded that growing area affected total phenolic content in the methanol extract of red calyx Rosell.

Keywords : Rosell (Hibiscus sabdariffa Linn), total phenolic, Folin ciocalteau method, variation of growing area

\section{PENDAHULUAN}

Rosella (Hibiscus sabdariffa Linn) adalah tanaman yang berasal dari Asia dan Afrika. Menurut penelitian yang dilakukan Usoh dkk (2005) kelopak bunga Rosella memiliki aktivitas antioksidan dengan nilai $\mathrm{IC}_{50}$ $0,20 \mathrm{mg} / \mathrm{ml}$. Senyawa fenolik pada kelopak bunga Rosella terdiri dari anthocyanins seperti delphinidin-3glucoside, delphinidin-3-sambubioside, dan cyanidin-3-sambubioside, kandungan flavonoid seperti gossypetin, hibiscetin, dan glukosida lainnya (Sonia dkk, 2007).

Mengingat pentingnya fungsi senyawa fenolik sebagai antioksidan, maka penelitian kadar fenolik total yang terkandung dalam tanaman Rosella dari berbagai tempat tumbuh perlu dilakukan. Dengan demikian pemanfaatan tanaman
Rosella dapat lebih maksimal untuk dijadikan sebagai alternatif pengobatan herbal dalam penyembuhan berbagai macam penyakit. Dengan melihat kadar fenolik total yang terkandung dalam ekstrak Rosella maka dapat diperkirakan besar aktivitas antioksidannya.

\section{METODO PENELITIAN}

\section{Bahan}

Bahan yang digunakan dalam penelitian ini adalah kelopak bunga rosella merah yang diperoleh dari Glagah (Dataran Rendah), Kediri (Dataran Sedang), Samigaluh (Dataran Tinggi) yang diambil pada bulan Februari 2011, reagen Folin ciocalteu p.a, metanol p.a (Merck), etanol p.a (Merck), asam galat p.a (Sigma), petroleum eter teknis (Brataco Chemica), aquadest (Brataco 
Chemica), feriklorida p.a (Merck), natrium karbonat p.a (Merck).

\section{Alat}

Peralatan yang digunakan dalam penelitian ini adalah alat-alat gelas, neraca analitik AND GR 202, aluminium foil, kuvet, kertas saring, rotary evaporator, spektrofotometer (UV-Vis Shimadzu UV PharmaSpec 1700), Halogen Moisturizer Analyzer (Mettler Toledo), alat maserasi, penangas air, mikropipet, corong Buchner.

\section{Jalannya Penelitian}

\section{Pembuatan ekstrak metanol}

Sebanyak 100,0 gram serbuk dilakukan pengawalemakkan dengan petroleum eter. Serbuk kemudian direndam dengan $350 \mathrm{ml}$ metanol sambil diaduk dengan distirer selama 3 jam, setelah didiamkan selama 24 jam, disaring dengan corong Buchner dan filtrat yang diperoleh dipekatkan dengan vaccum rotary evaporator.

\section{Uji pendahuluan adanya senyawa fenol}

\section{a. Uji Senyawa Polifenol}

Sejumlah ekstrak metanol kelopak bunga Rosella dari masing-masing tempat tumbuh ditambah dengan pereaksi $\mathrm{FeCl}_{3}$ sebanyak 3 tetes. Terjadinya warna hijau biru menunjukkan adanya polifenol.

\section{b. Uji Flavonoid}

Sejumlah ekstrak metanol kelopak bunga Rosella dari masing-masing tempat tumbuh dilarutkan dalam metanol, kemudian diteteskan pada kertas saring. Kertas saring tersebut dilewatkan pada uap amonia. Apabila terbentuk warna kuning intensif maka positif mengandung flavonoid.

c. Uji Tanin

Sejumlah ekstrak metanol kelopak bunga Rosella dari masing-masing tempat tumbuh dilarutkan dalam air suling dan dipanaskan selama 30 menit di atas penangas air, kemudian disaring. Filtrat ditambah larutan $\mathrm{NaCl} 2 \%$; bila terjadi endapan, disaring melalui kertas saring. Filtrat ditambah larutan gelatin 1\%; bila timbul endapan menunjukkan adanya tanin atau zat samak.

\section{Penetapan kadar fenolik total}

a. Pembuatan Reagen

1) Pembuatan larutan induk asam galat $(500 \mu \mathrm{g} / \mathrm{ml})$

Sebanyak 50,0 $\mathrm{mg}$ asam galat dilarutkan dalam $0,5 \mathrm{ml}$ etanol p.a, kemudian diencerkan dengan air suling sampai volume $100,0 \mathrm{ml}$.

2) Pembuatan larutan $\mathrm{Na}_{2} \mathrm{CO}_{3} 7,5 \%$

Sebanyak 7,5 $\mathrm{g} \mathrm{Na}_{2} \mathrm{CO}_{3}$ ditambah $80 \mathrm{ml}$ air suling, kemudian didihkan sampai serbuk $\mathrm{Na}_{2} \mathrm{CO}_{3}$ larut sempurna. Setelah itu diamkan selama 24 jam, disaring dan diencerkan dengan air suling sampai volume $100,0 \mathrm{ml}$.

b. Tahapan penentuan kadar senyawa fenolik total 


\section{1) Penentuan Operating Time}

Sebanyak $300 \mu 1$ larutan asam galat konsentrasi $30 \mu \mathrm{g} / \mathrm{ml}$ ditambah 1,5 $\mathrm{ml}$ reagen Folin Ciocalteau (1:10), kemudian digojog dan didiamkan selama 3 menit. Ke dalam larutan tersebut ditambah 1,2 ml larutan $\mathrm{Na}_{2} \mathrm{CO}_{3} 7,5 \%$, digojog homogen, dan diukur absorbansinya dalam rentang waktu 0-90 menit pada panjang gelombang $765 \mathrm{~nm}$.

\section{2) Penentuan Panjang Gelombang Absorbansi Maksimum}

Sebanyak $300 \mu 1$ larutan asam galat konsentrasi $30 \mu \mathrm{g} / \mathrm{ml}$ ditambah $1,5 \mathrm{ml}$ reagen Folin Ciocalteau (1:10), kemudian digojog dan didiamkan selama 3 menit. Ke dalam larutan tersebut ditambah 1,2 ml larutan $\mathrm{Na}_{2} \mathrm{CO}_{3} 7,5 \%$, digojog homogen, dan didiamkan pada suhu kamar pada range operating time, kemudian absorbansinya diukur pada panjang gelombang 600-850 $\mathrm{nm}$.

3) Pembuatan kurva baku asam galat dengan reagen Folin-Ciocalteau (Murtijaya dan Lim, 2007).

Sebanyak $300 \mu$ l larutan asam galat konsentrasi 5, 10, 15, 20, 25, 30, 35 dan $40 \mu \mathrm{g} / \mathrm{ml}$ masing-masing dimasukkan dalam tabung, kemudian ditambah 1,5 $\mathrm{ml}$ reagen Folin Ciocalteau (1:10) dan digojog. Setelah didiamkan selama 3 menit, masing-masing larutan ditambah $1,2 \mathrm{ml}$ larutan $\mathrm{Na}_{2} \mathrm{CO}_{3} \quad 7,5 \%$ digojog homogen, dan didiamkan pada range operating time pada suhu kamar. Semua larutan diukur absorbansinya pada panjang gelombang absorbansi maksimum, kemudian dibuat kurva kalibrasi hubungan antara konsentrasi asam galat $(\mu \mathrm{g} / \mathrm{ml})$ dengan absorbansi.
4) Penetapan kadar fenolik total (Murtijaya dan Lim, 2007)

Sebanyak 10,0 mg ekstrak metanol kelopak bunga Rosella merah dilarutkan sampai volume $10,0 \mathrm{ml}$ dengan campuran metanol : air suling (1:1). Larutan ekstrak yang diperoleh dipipet $300 \mu \mathrm{l}$ dan ditambah $1,5 \mathrm{ml}$ reagen Folin-Ciocalteau dan digojog. Didiamkan selama 3 menit, ditambah 1,2 $\mathrm{ml}$ larutan $\mathrm{Na}_{2} \mathrm{CO}_{3} 7,5 \%$ dan didiamkan lagi pada range operating time pada suhu kamar. Absorbansi larutan ekstrak diukur dengan spekrofotometer UV-Vis pada panjang gelombang absorbansi maksimum. Dilakukan 5 kali pengulangan.

\section{Analisis Data}

Analisis data terlebih dahulu dilakukan dengan metode kurva standar, regresi linier $\mathrm{y}=\mathrm{bx}+\mathrm{a}$ dibuat berdasarkan data absorbansi dan konsentrasi dari larutan standar.

\section{HASIL DAN PEMBAHASAN}

Uji polifenol dilakukan untuk memastikan adanya senyawa polifenol dalam kelopak bunga Rosella. Hasil uji polifenol ditandai dengan terjadinya reaksi antara senyawa polifenol dan ferri klorida membentuk senyawa kompleks berwarna hijau, ungu, biru.

Uji flavonoid dilakukan untuk memastikan ada tidaknya senyawa flavonoid yang merupakan bagian dari senyawa fenolik dalam kelopak bunga Rosella. Untuk itu, ekstrak yang dilarutkan dalam metanol ditotolkan pada kertas saring kemudian dikeringkan dan dilewatkan di atas uap amoniak. Warna kuning intensif yang timbul 
Tabel I. Hasil Uji Pendahuluan Adanya Senyawa Fenolik

\begin{tabular}{|c|c|c|c|c|c|}
\hline Sampel & $\begin{array}{c}\text { Uji } \\
\text { Kualitatif }\end{array}$ & Pereaksi & Teori & Hasil & Kesimpulan \\
\hline \multirow[t]{3}{*}{ Rosella Glagah } & Polifenol & $\mathrm{FeCl}_{3}$ & $\begin{array}{l}\text { Hijau, ungu, } \\
\text { biru atau } \\
\text { hitam }\end{array}$ & Hijau & + \\
\hline & Flavonoid & Uap Amoniak & $\begin{array}{l}\text { Kuning } \\
\text { intensif }\end{array}$ & Kuning & + \\
\hline & Tanin & \begin{tabular}{|l|}
$\mathrm{NaCl} 2 \%$ \\
Gelatin 1\% \\
\end{tabular} & $\begin{array}{l}\text { Terbentuk } \\
\text { endapan }\end{array}$ & $\begin{array}{l}\text { Terbentuk } \\
\text { endapan }\end{array}$ & + \\
\hline \multirow[t]{3}{*}{ Rosella Kediri } & Polifenol & $\mathrm{FeCl}_{3}$ & $\begin{array}{l}\text { Hijau, ungu, } \\
\text { biru atau } \\
\text { hitam }\end{array}$ & Hijau & + \\
\hline & Flavonoid & Uap Amoniak & $\begin{array}{l}\text { Kuning } \\
\text { intensif }\end{array}$ & Kuning & + \\
\hline & Tanin & $\begin{array}{l}\mathrm{NaCl} 2 \% \\
\text { Gelatin } 1 \% \\
\end{array}$ & $\begin{array}{l}\text { Terbentuk } \\
\text { endapan }\end{array}$ & $\begin{array}{l}\text { Terbentuk } \\
\text { endapan }\end{array}$ & + \\
\hline \multirow[t]{3}{*}{$\begin{array}{l}\text { Rosella } \\
\text { Samigaluh }\end{array}$} & Polifenol & $\mathrm{FeCl}_{3}$ & $\begin{array}{l}\text { Hijau, ungu, } \\
\text { biru atau } \\
\text { hitam }\end{array}$ & Hijau & + \\
\hline & Flavonoid & Uap Amoniak & $\begin{array}{l}\text { Kuning } \\
\text { intensif }\end{array}$ & Kuning & + \\
\hline & Tanin & $\begin{array}{l}\mathrm{NaCl} 2 \% \\
\text { Gelatin 1\% }\end{array}$ & $\begin{array}{l}\text { Terbentuk } \\
\text { endapan }\end{array}$ & $\begin{array}{l}\text { Terbentuk } \\
\text { endapan }\end{array}$ & + \\
\hline
\end{tabular}

menunjukkan adanya senyawa flavonoid. Warna kuning tersebut disebabkan karena pembentukan struktur kinoid yang mengandung ikatan rangkap terkonjugasi yang lebih panjang dan planar sehingga dapat berfluorosensi (Robinson, 1995).

Uji terhadap tanin dilakukan untuk memastikan apakah dalam kelopak bunga Rosella mengandung senyawa tanin. Salah satu sifat khas senyawa tanin adalah mempunyai kemampuan untuk mengendapkan protein, pada uji ini dikatakan positif apabila terbentuk endapan setelah penambahan gelatin (protein) pada larutan ekstrak.

Penetapan kadar fenolik total dilakukan dengan menggunakan reagen Folin-Ciocalteau. Reagen Folin Ciocalteau digunakan karena senyawa fenolik dapat bereaksi dengan Folin membentuk larutan berwarna yang dapat diukur absorbansinya. Prinsip dari metode folin ciocalteau adalah terbentuknya senyawa kompleks berwarna biru yang dapat diukur pada panjang gelombang $765 \mathrm{~nm}$. Pereaksi ini mengoksidasi fenolat (garam alkali) atau gugus fenolik-hidroksi mereduksi asam 
heteropoli (fosfomolibdat-fosfotungstat) yang terdapat dalam pereaksi Folin Ciocalteau menjadi suatu kompleks molibdenum-tungsten. Senyawa fenolik bereaksi dengan reagen Folin Ciocalteau hanya dalam suasana basa agar terjadi disosiasi proton pada senyawa fenolik menjadi ion fenolat. Untuk membuat kondisi basa digunakan $\mathrm{Na}_{2} \mathrm{CO}_{3} 7,5 \%$. Gugus hidroksil pada senyawa fenolik bereaksi dengan reagen Folin Ciocalteau membentuk kompleks molibdenumtungsten berwarna biru yang dapat dideteksi dengan spektrofotometer. Semakin besar konsentrasi senyawa fenolik maka semakin banyak ion fenolat yang akan mereduksi asam heteropoli (fosfomolibdat-fosfotungstat) menjadi kompleks molibdenum-tungsten sehingga warna biru yang dihasilkan semakin pekat.
Tabel I. Hasil Penetapan Kadar Fenolik Total Kelopak Bunga Rosella dengan variasi tempat tumbuh.

\begin{tabular}{|l|c|c|c|}
\hline Sampel & $\begin{array}{c}\text { Kadar } \\
\text { fenolik } \\
\text { total (g } \\
\text { GAE/100 g } \\
\text { ekstrak) }\end{array}$ & SD & n \\
\hline Glagah & 1,40 & 0,06 & 12 \\
\hline Kediri & 1,41 & 0,07 & 12 \\
\hline Samigaluh & 2,12 & 0,05 & 15 \\
\hline
\end{tabular}

Kadar fenolik total pada kelopak bunga Rosella merah di daerah Samigaluh paling besar dibanding di daerah Glagah dan Kediri. Hal ini didukung oleh hasil uji terhadap kandungan zat dalam kelopak bunga Rosella dari berbagai tempat tumbuh. Uji polifenol menunjukkan bahwa pada

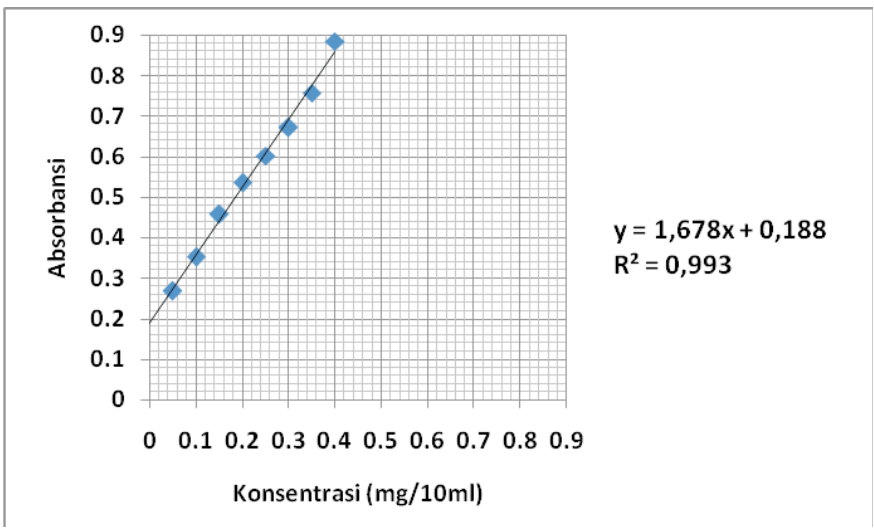

Gambar I. Grafik hubungan antara konsentrasi $(\mathrm{mg} / 10 \mathrm{ml})$ dan absorbansi larutan asam galat

Pada penentuan kadar fenolik total, larutan standar yang digunakan adalah asam galat dengan variasi konsentrasi 5, 10, 15, 20, 25, 30, 35, dan $40 \mu \mathrm{g} / \mathrm{ml}$. konsentrasi larutan ekstrak yang sama, larutan ekstrak kelopak bunga Rosella merah dari daerah Samigaluh membentuk komplek berwarna hijau yang paling pekat dibanding dengan larutan 
ekstrak kelopak bunga Rosella merah dari Glagah dan Kediri

Wilayah pegunungan, dimana curah hujan lebih tinggi dengan suhu lebih rendah, kecepatan penguraian bahan organik dan pelapukan mineral berjalan lambat. Sebaliknya di dataran rendah penguraian bahan organik dan pelapukan mineral berlangsung cepat. Karena itu di daerah pegunungan keadaan tanahnya relatif lebih subur, kaya bahan organik dan unsur hara jika dibandingkan dengan tanah di dataran rendah. Tinggi tempat berpengaruh terhadap suhu udara dan intensitas cahaya. Suhu dan intensitas cahaya akan semakin kecil dengan semakin tingginya tempat tumbuh. Cahaya berpengaruh langsung pada ketersediaan makanan. Klorofil dibentuk dari hasil fotosintesis dan berpengaruh secara langsung terhadap pertumbuhan setiap organ atau terhadap keseluruhan tumbuhan. Sebagian besar tumbuhan membentuk pigmen antosianin dan flavonoid lainnya yang merupakan senyawa fenolik dalam beberapa sel terspesialisasi di salah satu atau beberapa organnya, dan proses ini sering terpacu oleh cahaya. Akan tetapi matahari di wilayah Indonesia yang merupakan daerah tropis selalu bersinar hampir sepanjang tahun. Produksi flavonoid yang merupakan senyawa fenolik memerlukan gula sebagai sumber fosfoenolpiruvat dan eritrosa-4-fosfat yang menyediakan beberapa atom karbon yang diperlukan bagi cincin-B flavonoid, serta sebagai sumber unit asetat untuk cincin-A flavonoid. Gula, khususnya sukrosa, dapat diperoleh dari proses peruraian pati atau lemak di organ penyimpanan saat perkembangan kecambah, atau dari fotosintesis di sel yang mengandung klorofil (Salisbury dan Ross, 1992).

Dilihat dari kondisi tanah, tanah di daerah Samigaluh adalah jenis tanah kapur, tekstur halus dan sebagian bebatuan (Anonim ${ }^{\mathrm{b}}$ 2010). Di daerah pegunungan keadaan tanahnya relatif lebih subur, kaya bahan organik dan unsur hara. Tanah di daerah Glagah adalah tanah berpasir. Pada umumnya tanah pasir pantai mempunyai sifat-sifat yang kurang sesuai bagi pertumbuhan tanaman antara lain kurang mampu menyediakan air dan unsur hara sehingga tanaman pada umumnya mengalami defisiensi unsur hara dan kekurangan air (Syukur, 2005). Tanah di daerah Kediri adalah jenis tanah aluvial. Tanah aluvial memiliki tekstur yang cenderung kasar dengan kandungan senyawa organik dan unsur hara yang rendah dibanding tanah yang bertekstur lebih halus. Umumnya Rosella sendiri dapat tumbuh pada semua jenis tanah selama tanah tersebut kaya akan humus, gembur dan memiliki drainase yang baik (Widyanto dan Nelistya, 2009). Perbedaan kondisi tanah pada ketiga daerah tersebut menyebabkan terjadinya perbedaan kandungan senyawa fenolik dari tanaman Rosella yang tumbuh di daerah tersebut..

Pertumbuhan tanaman rosella dipengaruhi oleh banyak faktor, diantaranya adalah suhu, kelembaban, curah hujan dan ketinggian tempat tumbuh. Ketinggian tempat merupakan faktor yang menentukan kelanggengan suatu habitat. Penelitian ini dilakukan untuk menetapkan kadar fenolik total terhadap ketinggian tempat tumbuh. Kadar fenolik total yang didapat pada ekstrak metanol kelopak bunga Rosella merah 
pada daerah Glagah, Kediri dan Samigaluh berturut-turut adalah $1,40 \mathrm{~g}$ GAE/100g ekstrak, SD 0,06 dengan $\mathrm{n}=12 ; 1,4143$ g GAE/100g ekstrak, SD 0,07 dengan $\mathrm{n}=12$ dan $2,12 \mathrm{~g}$ GAE/ $100 \mathrm{~g}$ ekstrak, SD 0,05 dengan $\mathrm{n}=15$. Kadar dari daerah Samigaluh adalah daerah yang paling potensial dengan kandungan fenolik total paling besar.

\section{DAFTAR PUSTAKA}

Anonim 2010 ${ }^{\text {a }}$ Pemerintah Kabupaten Kediri,

http://www.kotakediri.go.id/?act= profile\&id=geografi\&tt=Geografi diakses Januari 2011.

Anonim 2010 ${ }^{\mathrm{b}}$, Pemerintah Kabupaten Kulon Progo, http://www.sidoharjokulonprogo. com/pages/57/Sumber Daya Ala

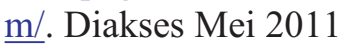

Murtijaya, J., dan Lim Y.Y., 2007, Antioxidant Properties of Phylanthus amarus Extracts as Affected by Different Drying Methods, LWT-Food Sci. Technol, 40, Hal 1664-1669.

Robinson, T., 1995, Kandungan Organik Tumbuhan Tinggi, Edisi VI, diterjemahkan oleh Kosasih Padmawinata, ITB press, Bandung, Hal 57, 73, 199.

Salisbury, B, F. dan Ross, W, C., 1992, Plant Physiologi, $4^{\text {th }}$ edition.
Wadsworth Publishing Co., A division of wadsworth, Inc, Jilid III, diterjemahkan oleh Dian R Lukman dan Sumaryono, ITB, Bandung.

Sonia G., Sayago-Ayerdi, Sara Arranz, Jose Serrano, and Isabel Goni, 2007, Dietary Fiber Content and Associated Antioxidant Compounds in Roselle Flower (Hibiscus sabdariffa Linn) Beverage. Laporan penelitian. Department of Nutrition, Faculty of Pharmacy, Universidad Complutense de Madrid, Spain.

Syukur, 2005, Pengaruh Pemberian Bahan Organik Terhadap Sifat-Sifat Tanah dan Pertumbuhan Caisim Di Tanah Pasir Pantai, Jurnal Ilmu Tanah dan Lingkungan Vol 5 (1).

Usoh, I.F, Akfan, Etim, Farombi., 2005, Antioxidant Actions of Dried Flower Extract of Hibiscus sabdariffa L. On Sodium Arsenite - Induced Oxidative Stress in Rats, Pakistan Journal of Nutrition 4 (3), Hal 135-141.

Widyanto, S dan Nelisya A., 2008, Rosela Aneka Olahan Khasiat \& Ramuan, Penebar Swadaya, Hal. 1,25 . 